\title{
The Development of Competencies in a Design Course from a Student Per- spective
}

\section{Dr. Warren F Smith, UNSW, Canberra, Australia}

Warren Smith is a Senior Lecturer in the School of Engineering and Information Technology, University of NSW, Canberra at the Australian Defence Force Academy. He joined the University in 1998 after spending 20 years as a practicing Naval Architect with the Australian Department of Defence. He is also an Affiliate Research Scholar at the University of Oklahoma. He is passionate about project-based authentic and immersive learning in engineering design education, believing design is learnt through doing. His passion is expressed in his own classes and through his roles as: National Coordinator for the Warman Design and Build Competition; FSAE Team Faculty Advisor; and Rules Chair and Facilitator for F1inSchools.

\section{Dr. Zahed Siddique, University of Oklahoma}

Zahed Siddique is a Professor of Mechanical Engineering at the University of Oklahoma. His research interests are in areas of product design, product platform design, and engineering education. He is interested in peer-to-peer learning, technology enhanced education, motivation, and game-based learning for engineering. He is the faculty advisor of the Sooner Racing Team (FSAE) and coordinator of the Mechanical Engineering Capstone Program.

\section{Prof. Farrokh Mistree, University of Oklahoma}




\title{
THE DEVELOPMENT OF COMPETENCIES IN A DESIGN COURSE FROM A STUDENT PERSPECTIVE
}

\begin{abstract}
A structured approach using surveys was implemented within the boundaries of an undergraduate design course to track progressively the changing student self-perceptions of competence during a semester long design activity. Using self-evaluation, the students were asked to reflect and articulate upon their own competency levels while being led through an ill structured system design, build and test experience. The subject course sits in the final year of a mechanical engineering undergraduate degree and has its focus on learning the principles of design in the context of the project which is a precursor to undertaking an industry sponsored capstone project. The hypothesis was that students would recognize their competencies developing through team-based and self-learning activities. The desire to understand students' awareness of their own learning and development is foundational / fundamental. Hence, the research questions are: (i) How do students perceive their competence while executing a design project? and, (ii) How does the perception of a set of competencies develop in design courses?

Presented in the paper is a list of competencies targeted for the course, a description of the course and a summary of some of the survey findings. Through better understanding and calibrating student perspectives, it follows that course design can be modified to better achieve course goals - a growth in competence. It was observed that students have emphatically shown that they have perceived increases in their competency level in a course but that they build their perceptions in phases: (i) an initial estimation based on performance in prior courses, (ii) calibration of their perceptions (often down) through the early formative feedback in the subject course and (iii) recovery and increase in perceived competence through greater awareness, reflection and experience.
\end{abstract}

\section{Motivation}

University education at the highest level of abstraction can be thought of as a process of developing personal competencies for identifying, understanding and resolving open problems (those that have not yet been solved) and for developing novel solutions. For engineering, these competencies can be both technical, rooted in the engineering sciences, and process based, involving leadership, teamwork and management. They require the engagement of creative and analytical skills and the execution of activities spanning divergent and convergent thinking. In engineering education, it is common for the national accrediting body to articulate the desired competencies to be found in graduating engineers. In various ways industry also has a say in what they expect from university education. Perhaps this is most clearly evident in the type of engineers certain companies employ and perhaps the statistics on employment may show a bias towards employing graduates from particular institutions in specific industry sectors.

Educators have reported on the benefits of experiential, hands-on, student-directed learning ${ }^{[1-4]}$ and the effects of design courses in engineering ${ }^{[5]}$. Engineering educators have used field trips, laboratory investigations, and interdisciplinary activities that enrich and extend the curriculum ${ }^{[6,7]}$. Such designing of authentic experiences into courses and curricula are consistent 
with the highly contextualized nature of professional engineering expertise ${ }^{[8]}$. Each of these application activities provides students with opportunities to apply different component skills from their engineering education, in different contexts and to different types of problems/situations ${ }^{[9]}$.

Design courses in general and the capstone in particular serve as platforms to facilitate this integrative application of basic science and engineering principles on ill structured problems that require students to first apply divergent thinking and then converge to one solution ${ }^{[10]}$. Even though project based design courses are introduced in the curriculum to provide engineering students with "real world" and "hands-on" design experiences to facilitate student learning, we lack the understanding from learning and cognitive theory that informs how these projects contribute to developing meta competencies. Hence the fundamental questions are:

- How do students perceive their competence while executing a design project?

- How does the perception of a set of competencies develop in design courses?

What is highlighted in this paper is a study of the development of competencies in a design course from a student perspective. A structured approach using surveys with IRB approval was implemented within the boundaries of an undergraduate design course to track progressively the changing student self-perceptions of competence during a semester long design activity.

\section{Competency Demands}

Recipes for undergraduate engineering education are provided by the relevant accrediting organizations, examples of which are ABET in the USA, and Engineers Australia (EA) in Australia. Competencies may be expressed implicitly or explicitly and they are embedded within the graduate attributes sought through an accredited education process. The substantial equivalence of accreditation systems and accredited programs across international boundaries has been recognized in the Washington, Sydney and Dublin Accords.

\section{Competencies for Future Engineers}

Corporations and employers have frequently pointed to a lack of professional awareness and low levels of communication and teamwork skills in engineering graduates ${ }^{[11-14]}$. These issues have led $\mathrm{ABET}^{[15]}$ to transform their accreditation criteria from a content-based approach to an outcomes-based approach. ABET now proposes to hold engineering schools accountable for the knowledge, skills, and professional values engineering students acquire (or fail to acquire) in the course of their education. Globalization and rapid changes in technology have led to changes in expected competencies of engineers. One of the main changes is the need for competencies related to innovation and creative problem-solving ${ }^{[16]}$. Various efforts have been taken to map competencies and curriculum and recent examples from the CDIO (Conceive-DesignImplement-Operate) domain include those of Armarego and Roy and Woollacott ${ }^{[17,18]}$.

Researchers have highlighted that the innovators of the future will need to be equipped with more than just specialization skills ${ }^{[19-21]}$. Innovation requires both information/knowledge and independent choice to initiate action ${ }^{[22]}$. Innovation is supported by both cognitive and affective/motivational factors, which, in turn, are informed by learning theory and research. Cognitive characteristics to support expertise development and innovation include depth of 
domain knowledge and skill, awareness of the situational factors that influence choices, and knowledge of adaptive task characteristics that may transfer to the current challenge ${ }^{[23]}$. Motivational and affective characteristics that support expertise development and innovation include self-efficacy ${ }^{[24]}$, self-determination ${ }^{[25]}$, and self-regulation ${ }^{[26]}$. Together they comprise an integrative framework to investigate, understand and promote innovation, learn to learn, and learn to create ${ }^{[22]}$.

There are two levels of competencies in any professional field, field-specific task competencies, and generalized skill sets, or meta-competencies. The task-specific competencies are benchmarks for graduates in a given field, that define them as well-prepared to meet job demands and excel in the future ${ }^{[27,28]}$. The general (meta) competencies are skill sets that enable them to function globally, such as in the ability to work with others, function in systems and meet organizational demands, and transfer task-specific skills to novel problems or tasks they have not encountered before ${ }^{[29-31]}$. Competencies are assumed to be identifiable, assessable, and relevant for practice ${ }^{[32,33]}$. The development of competencies to support engineering, in general, and innovation, in particular, is spiral in nature, with students building on some and adding new ones as they progress through the curriculum. Innovations in the future will increasingly come from teams of collaborators who can bring together multiple skills and perspectives. Different researchers have highlighted different sets of (meta) competencies that engineers of the future will require. Some of these for innovation, and as adapted for the subject course of this paper (AME 4163), are listed in Table 1. Broad categories to be considered are meta competencies to: manage information, manage thinking, manage collaboration, manage learning and manage attitude.

\section{Evidence of Competency Growth in Design Oriented Courses}

Ill structured problems significantly differ from classic well-structured and well-defined textbook problems, in that they require and promote critical thinking and problem solving experience. A well-structured problem has a right answer which can be found using an appropriate method. An ill structured problem is messy, it encompasses conflict, dilemmas need to be managed and solutions need to be reasoned and justified. Applying engineering principles to solve ill structured problems is a very challenging task for most students. They struggle when confronted with ambiguous challenges, as often faced in practice, where they need to use creative, constructive and analytical skills to formulate, solve and interpret results. One of the reasons for this is that much of engineering education continues in a "teacher-centered" mode that emphasizes content mastery that is supported by a reliance on standard text-book problems solved in well-defined step-by-step processes. These traditional teaching approaches common in the foundational courses fail to nurture the development of higher order cognitive skills needed by today's engineers. The traditional methods often fall short in moving students from acquiring to applying knowledge and creating solutions ${ }^{[34-37]}$. Instruction modes need to allow students to grow as critical thinkers with proficiency in learning and in creative problem solving for increasingly complex and uncertain engineering environments.

Prior work shows that students learn more effectively when actively involved in the learning process (e.g., ${ }^{[38]}$ ), and such active learning strategies promote higher order thinking. Accordingly, several learning approaches, such as project-, or problem-, or case studies-based learning, have been developed and applied in engineering courses, particularly design courses. 
These approaches allow students to learn through inquiry, which is a natural process of human learning by gathering information and processing data through applying the senses ${ }^{[39,40]}$. Bransford et al. ${ }^{[41]}$ observe that students learn best when presented with organized information that relates in some way to their own experiences, and when they are given the opportunity to test themselves on their own understanding and to work to develop their understanding with other students.

Table 1 - Meta competencies for Innovation (as adapted for AME 4163)

\begin{tabular}{|c|c|c|c|}
\hline Manage Information & \multicolumn{2}{|c|}{ Ability to Manage Thinking } & $\begin{array}{l}\text { Manage } \\
\text { Collaboration }\end{array}$ \\
\hline $\begin{array}{l}\text { - Ability to gather, } \\
\text { interpret, validate } \\
\text { and use information } \\
\text { - Understand } \\
\text { quantitative and } \\
\text { qualitative } \\
\text { information } \\
\text { - Discard useless } \\
\text { information }\end{array}$ & \multicolumn{2}{|c|}{$\begin{array}{l}\text { - Ability to identify and manage dilemmas } \\
\text { associated with the realization of } \\
\text { - Abmplex systems } \\
\text { - Holistic thinking } \\
\text { - Conceptual Thinking } \\
\text { - Ability to speculate and to identify } \\
\text { research topics worthy of investigation } \\
\text { - Divergent and convergent thinking } \\
\text { - Ability to engage in critical discussion } \\
\text { developify and explore opportunities for } \\
\text { - Abstems or services. } \\
\text { theory and methods }\end{array}$} & $\begin{array}{l}\text { - Ability to manage } \\
\text { the collaboration } \\
\text { process in local } \\
\text { settings } \\
\text { - Ability to create } \\
\text { new knowledge } \\
\text { collaboratively in a } \\
\text { diverse team } \\
\text { - Negotiating } \\
\text { competence } \\
\text { - Teamwork } \\
\text { competence }\end{array}$ \\
\hline \multicolumn{2}{|l|}{ Manage Learning } & \multicolumn{2}{|l|}{ Manage Attitude } \\
\hline \multicolumn{2}{|c|}{$\begin{array}{l}\text { - Ability to identify the competencies and meta- } \\
\text { competencies one need to develop to be } \\
\text { successful at creating value in a culturally } \\
\text { diverse, distributed engineering world } \\
\text { - Ability to self-instruct and self-monitor } \\
\text { learning } \\
\text { - Ability to interact with multiple modes of } \\
\text { learning }\end{array}$} & \multicolumn{2}{|c|}{$\begin{array}{l}\text {-Ability to self-motivate } \\
\text { - Ability to cope with chaos } \\
\text { - Ability to identify and acknowledge } \\
\text { mistakes and un-productive paths; } \\
\text { - Ability to assess and manage risk } \\
\text { taking }\end{array}$} \\
\hline
\end{tabular}

Courses with design projects are used in almost all contemporary engineering curriculum to ensure that students are able to transfer theoretical elements learned in traditional foundational and "engineering science" courses to an application that they have not encountered before. In addition, projects have been used to foster engagement, critical thinking, creativity, communication and other skills. In most curriculums, especially in Mechanical Engineering, there are several courses that are on topics of design. Providing an integrative experience, it is common for these courses to begin in the freshman year with an introduction to engineering; where the steps in the design process are at least briefly highlighted. There is usually then a later design course (or set of courses) that focuses on experiencing the steps in the design process which allows students to design and develop products from customer requirements. The design 
course sequence thus provides an environment for the development of competencies related to structured and creative problem solving.

\section{A Study - Principles of Design (AME 4163)}

A study has been made of the higher level course, Principles of Design (AME 4163), a senior mechanical engineering design course at the University of Oklahoma ${ }^{1}$. In this course students are provided with an opportunity to explore and experience issues and tools related to design.

Students are guided through a structured design process, with an emphasis on the development of digital prototypes and using them for analysis prior to build. One student learning objective is to gain a better understanding of and confidence in the execution of the design process itself. Another addresses learning, by encouraging students to observe and reflect upon their own journey. Attempts are made to excite them in their own development aiming to instill a desire for life-long learning. It follows that of specific interest to the academics involved are the following:

1. facilitating the development of competencies and meta competencies in the course through course design,

2. understanding how students achieve the course learning objectives, and

3. measuring how successful students were in achieving the course learning objectives.

In AME 4163, a design process that combines steps from several general prescriptive models of designing is introduced to the students (as outlined in Figure 1). Lectures and assignments in the course are related to leading students explicitly through these steps in the design process. The students self-form groups, typically of 4 students, and work on a semester-long design and build task. The task is the same for all groups in a given semester and is assigned at the beginning of the semester through a published scenario and set of rules. The task is different for each offering of the course. The details of the task are not relevant to this paper but to provide context, in 2013, the project requirement was to build an autonomous device that would climb an eight foot mesh inclined ramp of 60 degrees and release powder onto a horizontal platform at the top to hypothetically extinguish a fire. In 2012, students were to build a system to support field athletic events by autonomously transporting shot puts, discuses and javelins in specified quantities over a grassed field to the throwing area. Each project has its own constraints and goals.

It is expected that at the end of the semester the students will:

1. Be able to apply a systematic approach to solve design problems.

2. Have the ability to plan the design process.

3. Have the ability to generate, evaluate and develop design concepts by applying knowledge of facts, science, engineering science, and manufacturing principles.

4. Have the ability to use analysis and simulation tools to understand design performance and then improve the design.

5. Have experience in manufacturing a design prototype.

6. Have generated solid models and engineering drawings of their final design using 3D modeling software.

7. Have given an oral presentation and demonstration of their design project.

8. Have experienced working on a team to complete a design project.

An overview of topics covered in the course is provided in Table 2.

\footnotetext{
${ }^{1}$ For detailed information about the course, contact Zahed Siddique at zsiddique@ou.edu.
} 


\section{Targeted Competencies in AME 4163}

The course, AME 4163, starts with a lecture on competencies and meta competencies. The students are then given a short assignment as outlined in Table 3, where the objective for students is to critically assess their current competencies, realize competencies that they will need to be successful as future engineers, and within the course framework define how they will develop these competencies. This theme of competency development is then continuously emphasized throughout the course encouraging students to explicitly consider their learning journey.

It is desired that learners in AME4163 develop higher order habits of mind. Self-regulated learners believe that opportunities to take on challenging tasks, practice their learning, develop a deep understanding of subject matter, and exert effort will give rise to academic success. Consistently engaging in higher level cognitive activities and achieving the higher level objectives of analysis, synthesis, and evaluation involve more than following a new set of procedures as discussed by Bloom ${ }^{[34]}$. Some of the specific competencies that are targeted in AME 4163 are shown in Table 1.

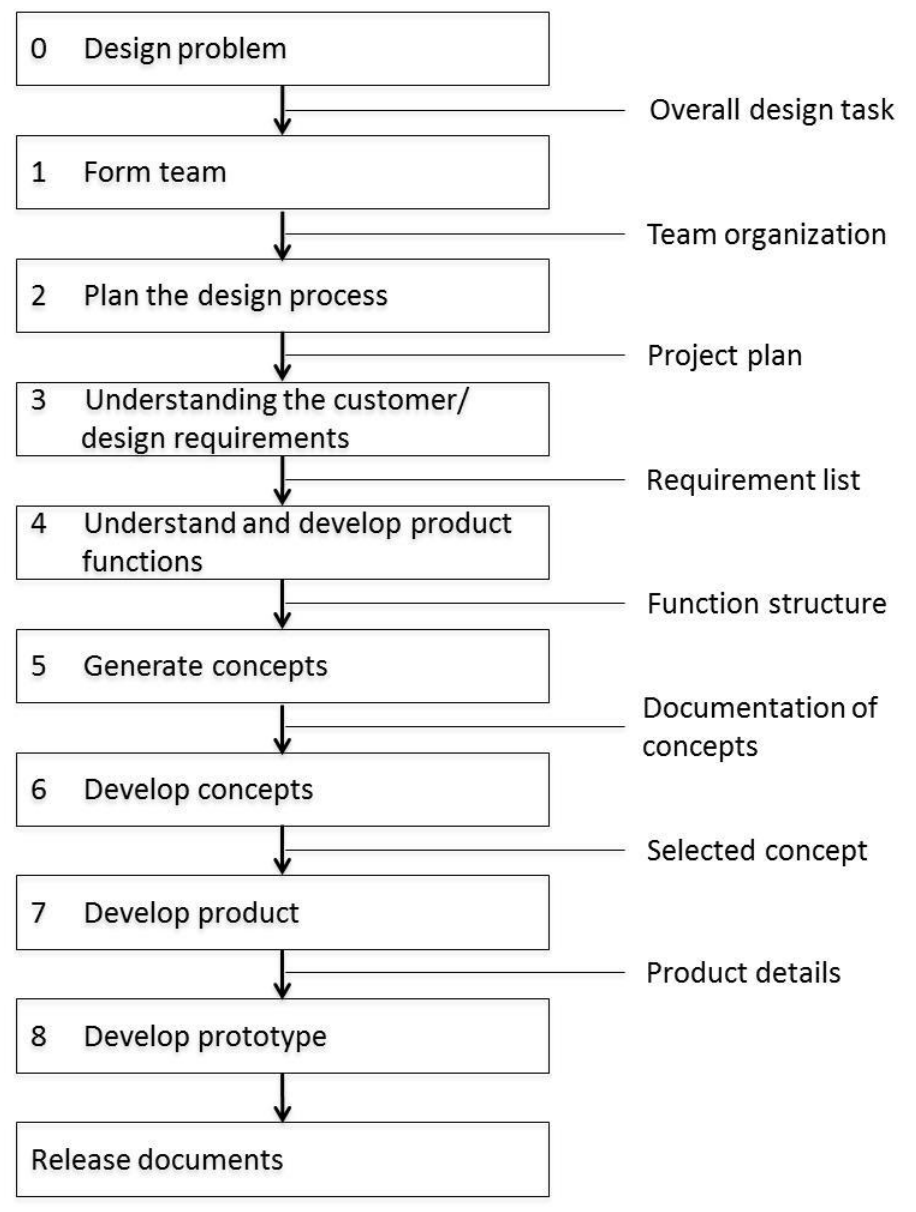

Figure 1 - Design Process 
Table 2 - AME 4163 Syllabus

\begin{tabular}{|c|c|c|}
\hline Week & Lecture Topic & Items Due $\quad$ SA: Short Assignments \\
\hline 1 & $\begin{array}{l}\text { Introduction and forming teams } \\
\text { Basic team organization } \\
\text { Steps in the design processes } \\
\text { Meta design and scheduling } \\
\text { Designing and managing the process }\end{array}$ & \\
\hline 2 & $\begin{array}{l}\text { Building and testing bridges } \\
\text { Machine shop tour } \\
\text { Safety instructions }\end{array}$ & $\begin{array}{l}\text { SA: Team form } \\
\text { SA: Setting goals and evaluating your competencies } \\
\text { SA: Understanding the design process - bridge }\end{array}$ \\
\hline 3 & $\begin{array}{l}\text { Understanding customer needs, } \mathrm{HoQ} \\
\text { List of requirements }\end{array}$ & $\begin{array}{l}\text { Assignment 1A: Problem Definition and Planning } \\
\text { Survey 1A }\end{array}$ \\
\hline 3 & $\begin{array}{l}\text { Function structure } \\
\text { Generation of concepts }\end{array}$ & \\
\hline 4 & Concept evaluation & $\begin{array}{l}\text { Assignment 1B: Customer Needs } \\
\text { Survey 1B }\end{array}$ \\
\hline $5-6$ & $\begin{array}{l}\text { CAD modeling and simulation } \\
\text { Basic animation with SolidWorks Motion } \\
\text { FEA -introduction and brief overview } \\
\text { (structural and heat transfer) }\end{array}$ & $\begin{array}{l}\text { Assignment 2A: Function Structure and Concepts } \\
\text { Survey 2A } \\
\text { Assignment 2B: Concept Evaluation } \\
\text { Survey 2B }\end{array}$ \\
\hline $7-8$ & CFD - introduction and brief overview & $\begin{array}{l}\text { Assignment 3A: CAD Modeling and Analysis } \\
\text { Assignment 3B: Simulation Based Design - FEA and } \\
\text { CFD Analysis of Concepts }\end{array}$ \\
\hline 9 & $\begin{array}{l}\text { Build prototype } \\
\text { Design for assembly } \\
\text { Design for life-cycle }\end{array}$ & \\
\hline $10-11$ & $\begin{array}{l}\text { Ethics } \\
\text { Build prototype }\end{array}$ & $\begin{array}{l}\text { Assignment 4: Detail Design } \\
\text { Survey } \mathbf{3} \mathbf{\&} \mathbf{4}\end{array}$ \\
\hline 11 & Project demonstration & \\
\hline 12 & Project presentations & \\
\hline $13-15$ & Capstone project - introduction & $\begin{array}{l}\text { Final report } \\
\text { Learning essay } \\
\text { SA: Professional and ethical responsibilities }\end{array}$ \\
\hline
\end{tabular}

Table 3: Short Assignment on Competencies

\section{Short Assignment 3: Setting Goals AND Evaluating Your Competencies}

\section{Please read the document titled "Setting Goals and Evaluating Your Competencies"}

In AME 4163 you will have the opportunity to develop some of the competencies and meta competencies needed by engineers for the innovation economy. As an engineer you will have to not only develop, but also master some of these (meta) competencies. In this short assignment I am challenging you to:

1. Perform a self-evaluation of your technical competencies and meta-competencies.

2. What are the competencies (technical and meta) you think you will need to survive in the innovation economy?

3. Which of these competencies (technical and meta) would you like to develop or master in AME 4163 ?

4. How will you (not the instructor) take charge and develop these competencies (technical and meta) at the desired level?

5. How will you assess yourself throughout and at the end of the semester to ensure that you have developed/mastered these competencies (technical and meta)? 


\section{Method and Instrument}

To assess student perceptions, IRB approval was obtained to conduct student surveys in AME 4163. The data was collected using an online "quiz" mechanism within "Desire2Learn" environment; the University's learning management system.

A total of 46 questions were asked across 5 surveys (coded as $1 \mathrm{~A}, 1 \mathrm{~B}, 2 \mathrm{~A}, 2 \mathrm{~B}$ and $3 \& 4$ in line with the assignment schedule). From survey to survey, students were not provided feedback on how they had previously responded to the questions asked and it was hoped that they would answer in accordance with their current perceptions independently of prior assessments. The administration sequence of the surveys is shown in Table 2. Each survey response window closed following the submission of a significant element of assessment as students progressed through the design process. The questions asked were tailored to address the experiences to that point in the course.

Shown in the respective columns to the right in Table 4 are the questions asked in each survey. A blank indicates the question was not asked. In Survey 1A, questions related to but not explicitly questions 1, 16, 17 and 20 were asked as questions 37-40 (on planning) and 42-46 (on teamwork).

Some questions were asked just once and others that were relevant were asked in each survey in an effort to track changing perceptions. The global question number for the survey series is given in column one and all data has been adjusted to align with this referencing.

In Survey 1A (question 41), students were asked about how they formed their project teams. Possible responses and the number and percentage of the class responding in this way were:

1. I teamed with strangers (responses 11/66, 16.7\%),

2. I teamed with people who lived near me (responses $0 / 66,0 \%$ ),

3. I teamed with my friends/study partners (responses $43 / 66,65.2 \%$ ),

4. I teamed with people who had similar time availability (responses $2 / 66,3.0 \%$ ),

5. I teamed with people who had similar aspiration for class (responses 8/66, 12.1\%), and

6. Other (responses $2 / 64,3.0 \%$ ).

It is interesting to note but it is not surprising that two-thirds of the class when given the chance to work with friends/study partners did so. On the other side of this circumstance, onethird of the class worked with "strangers".

In questions 1-24, (and 37-40 and 42-46) students were asked to answer to the best of their ability with a response to how true each statement was for them from their perspective. A seven point scale was used as follows:

1. Very Much Untrue

2. Moderately Untrue

3. Mildly Untrue

4. Neither True nor Untrue

5. Somewhat True

6. Mostly True

7. Very Much True 
These questions dealt with competency development across five broad areas (as previously discussed):

1. Ability to Manage Information and Processes

2. Ability to Manage Thinking

3. Ability to Manage Collaboration

4. Ability to Manage Learning

5. Ability to Manage Attitude

Another set of questions, 25-36, solicited information on teamwork. The students were asked "at this stage of the project and from your perspective, how well did the team work together on various aspects of the project?" Again, a seven point scale was used as follows:

1. Very Poor

2. Moderately Poor

3. Mildly Poor

4. Neither Poor nor Well

5. Somewhat Well

6. Mostly Well

7. Very Well

Given the breadth of questioning, the focus for detailed presentation of results and discussion herein will be on questions asked repeatedly in surveys 1B, 2A, 2B and $3 \& 4$ and those specifically targeting the development of competency. This leads to an analysis of questions 1,3 , $4,7,16,17,20,22,23$, and 24 as highlighted in Table 4 - the 10 consistently asked competency questions.

The class of 2013 comprised 76 students. As shown in Figure 2, the most number of students, 66 , responded to Survey 1A, while the least number of respondents was 44 for Survey $2 \mathrm{~A}$. Across the five surveys, 24 of 76 responded to all five surveys and only two students failed to respond to at least one survey.

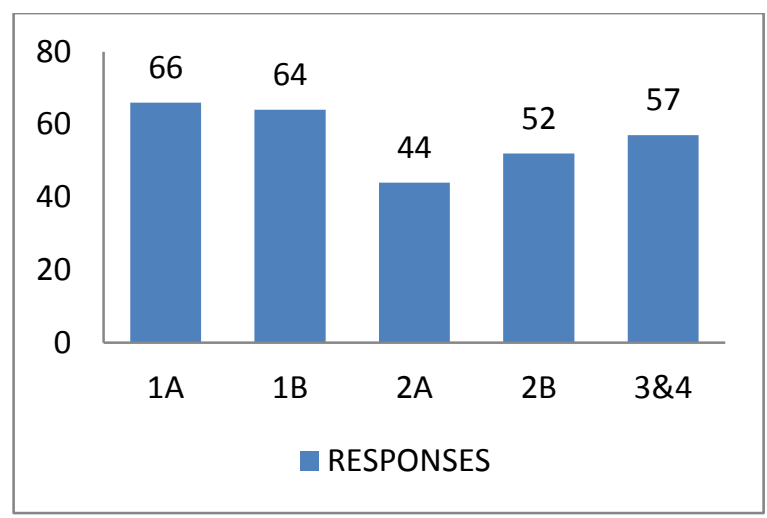

(a)

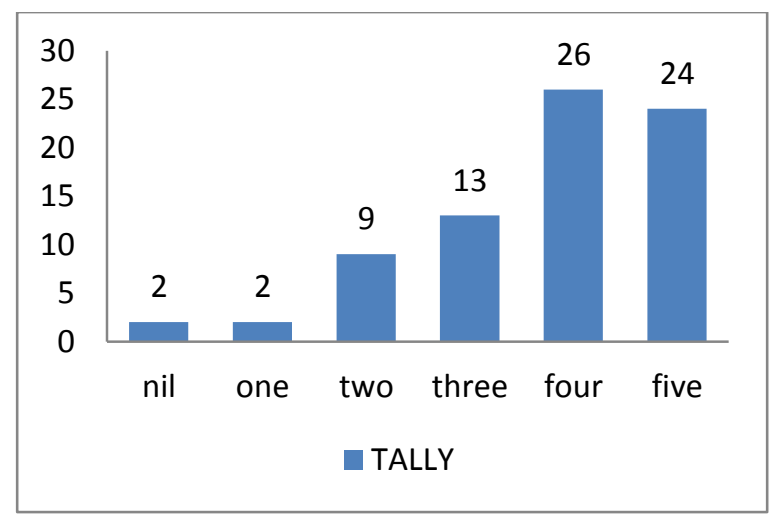

(b)

Figure 2 - Survey Statistics;

(a) Responses to each survey and

(b) Tally of surveys completed by individuals 
Table 4 - The Survey Questions and the Surveys in which they were asked (Highlighted: 1,3,4,7,16,17,20,22,23,24- 10 consistently asked competency questions)

\begin{tabular}{|c|c|c|c|c|c|c|}
\hline Q\# & Question & $1 \mathrm{~A}$ & $1 \mathrm{~B}$ & $2 \mathrm{~A}$ & $2 \mathrm{~B}$ & $3 \& 4$ \\
\hline & ABILITY TO MANAGE INFORMATION AND PROCESSES & & & & & \\
\hline 1 & I am confident in my ability to scope, plan and manage a process & * & 1 & 1 & 1 & 1 \\
\hline 2 & I am confident in my ability to gather, interpret, validate and use information & & & & 2 & 2 \\
\hline 3 & I am confident in my ability to understand and use quantitative and qualitative information & & 3 & 3 & 3 & 3 \\
\hline \multirow[t]{2}{*}{4} & I am confident in my ability to discard useless information & & 4 & 4 & 4 & 4 \\
\hline & ABILITY TO MANAGE THINKING & & & & & \\
\hline 5 & I am confident in my ability to identify and manage dilemmas associated with the realization of a system & & & & & 5 \\
\hline 6 & I am confident in my ability to think across disciplines (interdisciplinary) & & & 6 & 6 & 6 \\
\hline 7 & I am confident in my ability to think holistically (big picture, top down) & & 7 & 7 & 7 & 7 \\
\hline 8 & I am confident in my ability to think conceptually & & & 8 & 8 & 8 \\
\hline 9 & I am confident in my ability to speculate and to identify questions worthy of investigation & & & & & 9 \\
\hline 10 & I am confident in my ability to use divergent thinking (considering possibilities, research, explore) & & & 10 & 10 & 10 \\
\hline 11 & I am confident in my ability to use convergent thinking (make decision) & & & & & 11 \\
\hline 12 & I am confident in my ability to engage in critical thinking and discussion & & & 12 & 12 & 12 \\
\hline 13 & I am confident in my ability to identify opportunities for developing innovative products & & & & 13 & 13 \\
\hline \multirow[t]{2}{*}{14} & I am confident in my ability to think strategically using both theory and methods & & & & & 14 \\
\hline & ABILITY TO MANAGE COLLABORATION & & & & & \\
\hline 15 & I am confident in my ability to create new knowledge collaboratively in a team & & & 15 & 15 & 15 \\
\hline 16 & I am confident in my ability to negotiate effectively & ${ }^{*}$ & 16 & 16 & 16 & 16 \\
\hline \multirow[t]{2}{*}{17} & I am confident in my ability to team effectively with others & ${ }^{*}$ & 17 & 17 & 17 & 17 \\
\hline & ABILITY TO MANAGE LEARNING & & & & & \\
\hline 18 & I am confident in my ability to identify the required competencies and meta-competencies I and my team need to be successful & & & 18 & 18 & 18 \\
\hline 19 & I am confident in my ability to self-instruct and self-monitor & & & & & 19 \\
\hline \multirow[t]{2}{*}{20} & I am confident in my ability to learn through different modes (lecture, team discussions, reading, reserach) & ${ }^{*}$ & 20 & 20 & 20 & 20 \\
\hline & ABILITY TO MANAGE ATTITUDE & & & & & \\
\hline 21 & I am confident in my ability to self-motivate & & & & & 21 \\
\hline 22 & I am confident in my ability to cope with chaos & & 22 & 22 & 22 & 22 \\
\hline 23 & I am confident in my ability to identify and acknowledge mistakes and un-productive paths & & 23 & 23 & 23 & 23 \\
\hline \multirow[t]{2}{*}{24} & I am confident in my ability to assess and manage risk-taking & & 24 & 24 & 24 & 24 \\
\hline & TEAMWORK (Part 1) & & & & & \\
\hline 25 & How well did the team work together on: Understanding the requirements & 25 & 25 & 25 & 25 & 25 \\
\hline 26 & How well did the team work together on: Meeting together & 26 & 26 & 26 & 26 & 26 \\
\hline 27 & How well did the team work together on: Listening to everyone's ideas & 27 & 27 & 27 & 27 & 27 \\
\hline 28 & How well did the team work together on: Decision making & 28 & 28 & 28 & 28 & 28 \\
\hline 29 & How well did the team work together on: Written communication & 29 & 29 & 29 & 29 & 29 \\
\hline 30 & How well did the team work together on: Design documentation & 30 & 30 & 30 & 30 & 30 \\
\hline 31 & How well did the team work together on: How to work in a group & & 31 & 31 & 31 & 31 \\
\hline 32 & How well did the team work together on: How to carry out a project & & 32 & 32 & 32 & 32 \\
\hline 33 & How well did the team work together on: Importance of organization & & 33 & 33 & 33 & 33 \\
\hline 34 & How well did the team work together on: Skills in organization & & 34 & 34 & 34 & 34 \\
\hline 35 & How well did the team work together on: Skills in problem solving & & 35 & 35 & 35 & 35 \\
\hline \multirow[t]{2}{*}{36} & How well did the team work together on: Estimating time to complete a project & & 36 & 36 & 36 & 36 \\
\hline & PLANNING & & & & & \\
\hline 37 & I am confident in my ability to identify steps needed for successful design & 37 & & & & \\
\hline 38 & I am confident in my ability to logically structure and manage the steps needed for successful design & 38 & & & & \\
\hline 39 & I am confident in my ability to identify the resources needed to complete the steps in a design process & 39 & & & & \\
\hline \multirow[t]{2}{*}{40} & I am confident in my ability to properly allocate the resources needed to complete the steps in a design process & 40 & & & & \\
\hline & TEAMWORK (Part 2) & & & & & \\
\hline 41 & For the Project, which statement best describes how your team was formed? & 41 & & & & \\
\hline 42 & I am confident in my ability to establish roles and responsibilites in a team environment & 42 & & & & \\
\hline 43 & I am confident in my ability to set modes of operation for productive teamwork & 43 & & & & \\
\hline 44 & I am confident in my ability to resolve conflict in a team environment & 44 & & & & \\
\hline 45 & I am confident in my ability to communicate my perspectives and concepts to my team & 45 & & & & \\
\hline 46 & I am confident in my ability to build team consensus to make decisions & 46 & & & & \\
\hline
\end{tabular}




\section{Results and Observations from the "Ten Competency Questions"}

For the ten competency questions asked in all four surveys, the mean responses are shown in Figure 3. Two views are provided: (a) from survey to survey, where some dips are evident in the mean values and (b) from the first to the last survey where there is an increase in the mean in all cases indicating a class perception of increased competence.

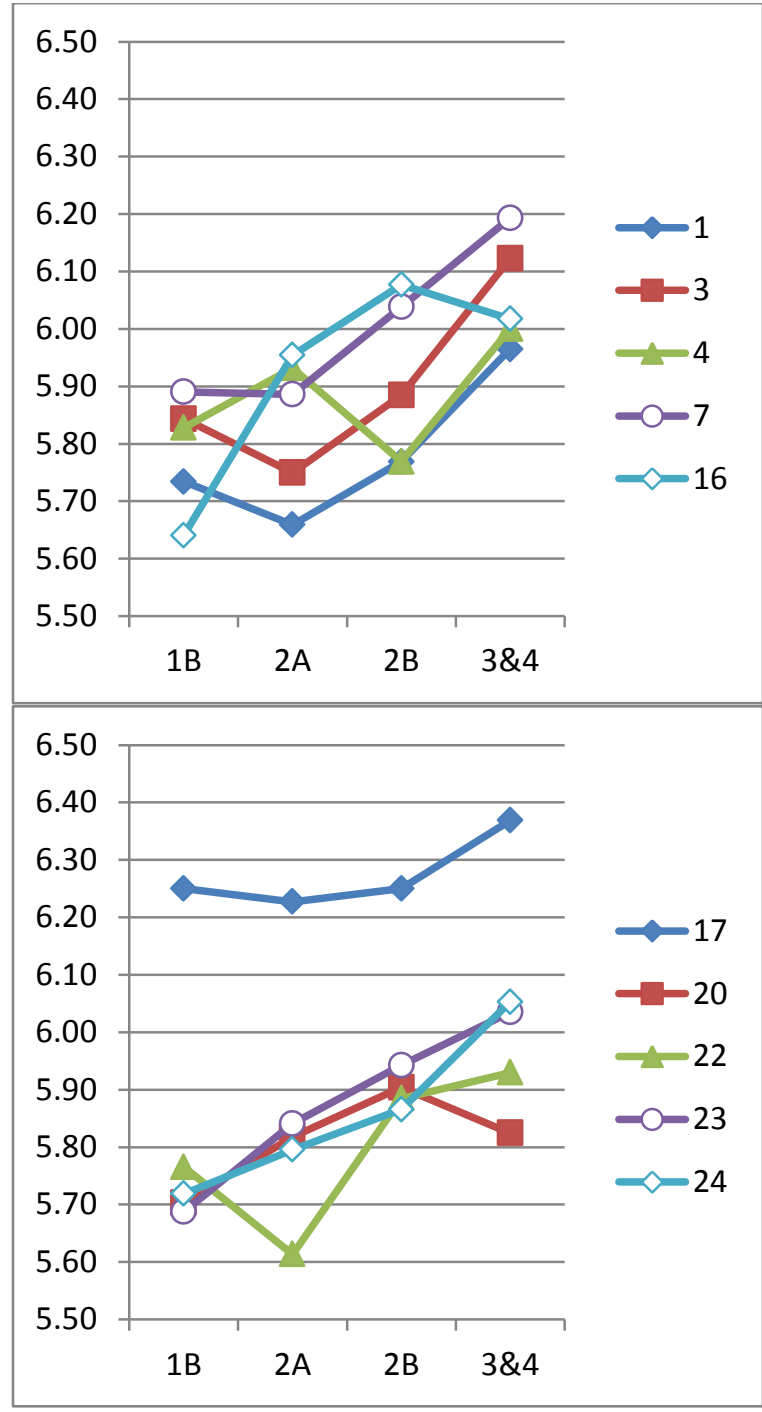

(a) from survey to survey

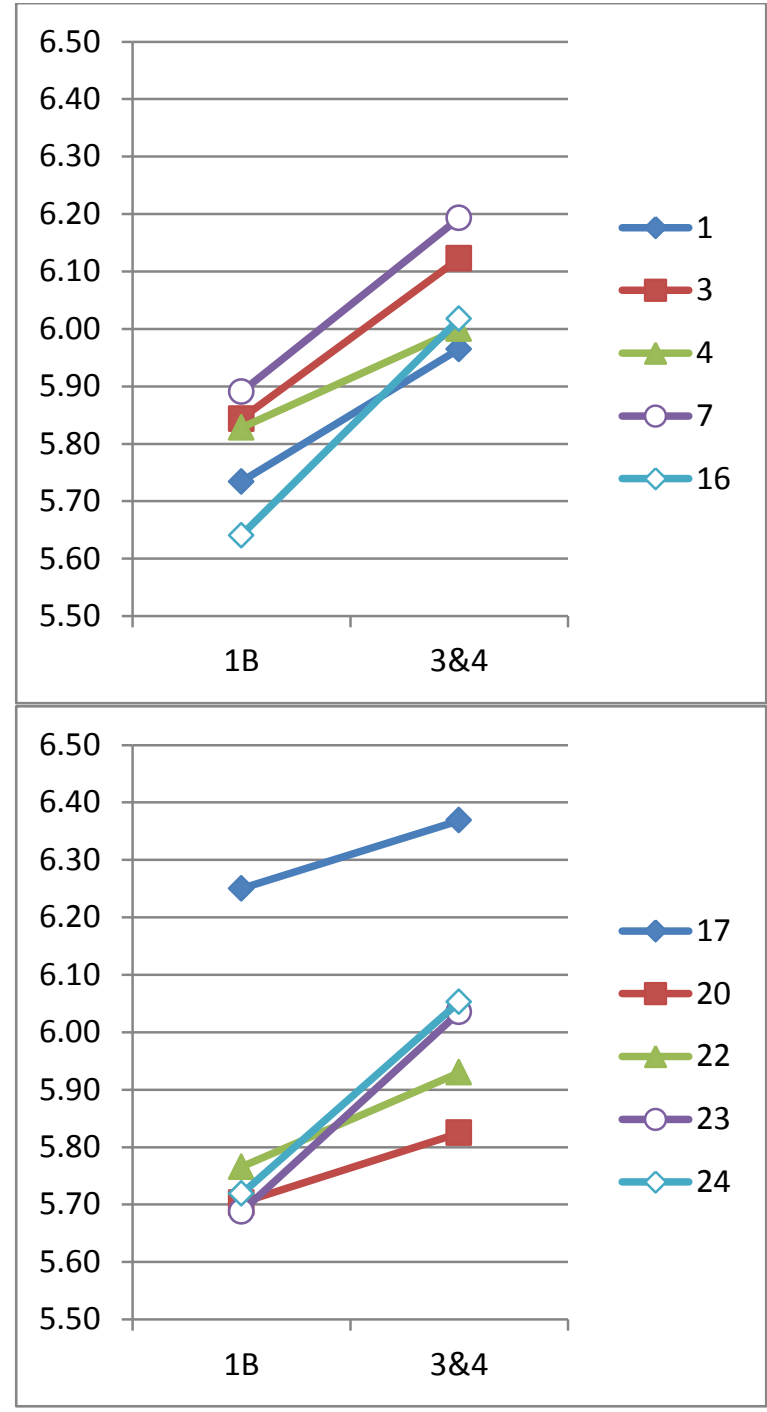

(b) from first survey to last survey

Figure 3 - Mean Responses to 10 Questions

KEY: I am confident in my ability to:

Q1-Scope, plan and manage a process

Q3-Understand and use quantitative and qualitative information

Q4-Discard useless information

Q7-Think holistically

Q16-Negotiate effectively
Q17-Team effectively

Q20-Learn through different modes

Q22-Cope with chaos

Q23-Identify and acknowledge mistakes and un-productive paths

Q24-Access and manage risk-taking 
It is interesting to note that Question 16 (I am confident in my ability to negotiate effectively) dipped during the last survey, which is when students were developing and constructing their design project. A similar dip is also seen in Question 20 (I am confident in my ability to learn through different modes). We hypothesize that this dip is due to decisions related to the performance of the prototype not meeting expectation and students having identified lower learning value to the experience. In some other instances there was an initial dip in perceived competencies. We believe this is due to student adjusting and calibrating their perceived level of competencies. The perceived level of competencies then recovered as students completed additional tasks and were able to further develop their competencies.

Shown in Table 5 are the descriptive statistics of the responses to the 10 questions. While the mean values have been plotted in Figure 3, the highest and lowest standard deviation values are 1.205 and 0.805 respectively. In all but one case (Question 7), the variance can be seen to be decreasing for that question from the first to the last survey.

In Figures 4, 5 and 6, a histogram of the responses to each of the 10 question are shown. By examination it can again be seen that the mean is shifting to the right and while not explicitly calculated, the variance in general is contracting. These changes can be visualized by comparing the curve associated with each survey's distribution. This shift in mean indicates that students in design courses perceive that they are improving their competencies as they progress through the semester and engage with the authentic experiential activities.
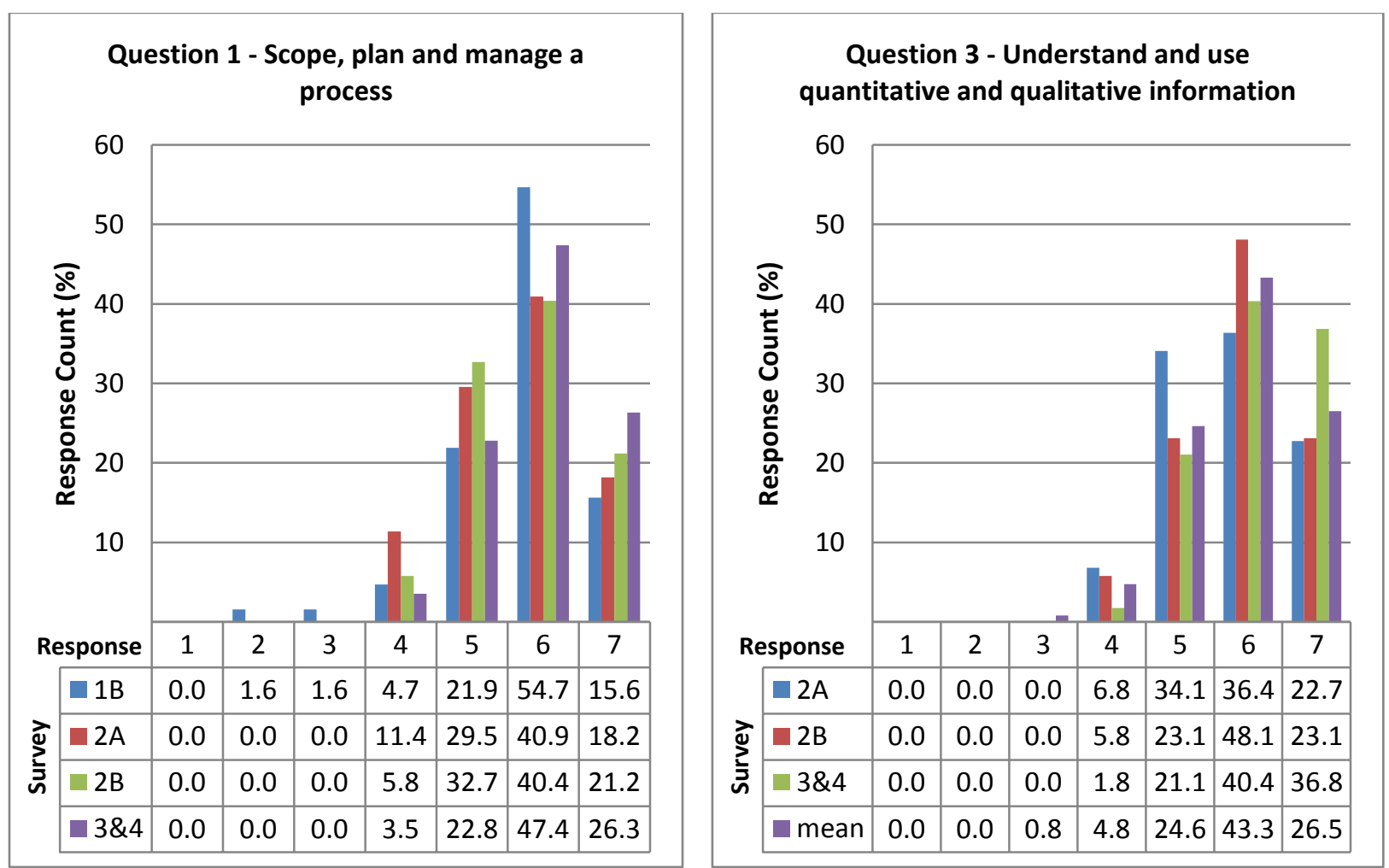

Figure 4 - Histograms of Response Count (\%) across Surveys - Questions 1 and 3 
Table 5 - Descriptive Statistics of the Responses to the 10 Questions

\begin{tabular}{|c|c|c|c|c|c|c|c|c|}
\hline \multirow{2}{*}{$\begin{array}{c}\text { Question_ } \\
\text { Survey }\end{array}$} & \multirow{2}{*}{$\frac{\mathrm{N}}{\text { Statistic }}$} & \multirow{2}{*}{$\begin{array}{l}\text { Range } \\
\text { Statis tic }\end{array}$} & \multirow{2}{*}{$\frac{\text { Minimum }}{\text { Statistic }}$} & \multirow{2}{*}{$\frac{\text { Maximum }}{\text { Statistic }}$} & \multicolumn{2}{|c|}{ Mean } & \multirow{2}{*}{$\begin{array}{c}\text { Std. } \\
\text { Deviation }\end{array}$} & \multirow{2}{*}{$\frac{\text { Variance }}{\text { Statistic }}$} \\
\hline & & & & & Statistic & Std. Error & & \\
\hline 1_1B & 64 & 5 & 2 & 7 & 5.73 & .118 & .947 & .897 \\
\hline $1 \_2 A$ & 44 & 3 & 4 & 7 & 5.66 & .138 & .914 & .835 \\
\hline 1_2B & 52 & 3 & 4 & 7 & 5.77 & .118 & .854 & .730 \\
\hline 1_3\&4 & 57 & 3 & 4 & 7 & 5.95 & .107 & .811 & .658 \\
\hline 3_1B & 64 & 4 & 3 & 7 & 5.84 & .118 & .946 & .896 \\
\hline 3_2A & 44 & 3 & 4 & 7 & 5.75 & .135 & .892 & .797 \\
\hline 3_2B & 52 & 3 & 4 & 7 & 5.88 & .115 & .832 & .692 \\
\hline 3_3\&4 & 57 & 3 & 4 & 7 & 6.11 & .111 & .838 & .703 \\
\hline 4_1B & 64 & 6 & 1 & 7 & 5.83 & .142 & 1.135 & 1.287 \\
\hline 4_2A & 44 & 3 & 4 & 7 & 5.93 & .143 & .950 & .902 \\
\hline 4_2B & 52 & 3 & 4 & 7 & 5.77 & .122 & .877 & .769 \\
\hline 4_3\&4 & 57 & 3 & 4 & 7 & 5.96 & .128 & .963 & .927 \\
\hline 7_1B & 64 & 4 & 3 & 7 & 5.89 & .120 & .961 & .924 \\
\hline $7 \_2 A$ & 44 & 3 & 4 & 7 & 5.89 & .139 & .920 & .847 \\
\hline $7 \_2 B$ & 52 & 3 & 4 & 7 & 6.04 & .120 & .862 & .744 \\
\hline 7_3\&4 & 57 & 4 & 3 & 7 & 6.18 & .130 & .984 & .969 \\
\hline 16_1B & 64 & 5 & 2 & 7 & 5.64 & .132 & 1.060 & 1.123 \\
\hline 16_2A & 44 & 3 & 4 & 7 & 5.95 & .156 & 1.033 & 1.068 \\
\hline 16_2B & 52 & 3 & 4 & 7 & 6.08 & .122 & .882 & .778 \\
\hline $16 \_3 \& 4$ & 57 & 3 & 4 & 7 & 6.02 & .119 & .896 & .803 \\
\hline 17_1B & 64 & 4 & 3 & 7 & 6.25 & .111 & .891 & .794 \\
\hline 17_2A & 44 & 3 & 4 & 7 & 6.23 & .125 & .831 & .691 \\
\hline 17_2B & 52 & 3 & 4 & 7 & 6.25 & .116 & .837 & .701 \\
\hline 17_3\&4 & 57 & 3 & 4 & 7 & 6.35 & .108 & .813 & .660 \\
\hline 20_1B & 64 & 4 & 3 & 7 & 5.70 & .144 & 1.150 & 1.323 \\
\hline 20_2A & 44 & 4 & 3 & 7 & 5.82 & .146 & .971 & .943 \\
\hline 20_2B & 52 & 4 & 3 & 7 & 5.90 & .135 & .975 & .951 \\
\hline 20_3\&4 & 57 & 5 & 2 & 7 & 5.86 & .143 & 1.076 & 1.159 \\
\hline 22_1B & 64 & 5 & 2 & 7 & 5.77 & .146 & 1.165 & 1.357 \\
\hline 22_2A & 44 & 5 & 2 & 7 & 5.61 & .182 & 1.205 & 1.452 \\
\hline 22_2B & 52 & 4 & 3 & 7 & 5.88 & .147 & 1.060 & 1.124 \\
\hline 22_3\&4 & 57 & 3 & 4 & 7 & 5.91 & .133 & 1.005 & 1.010 \\
\hline 23_1B & 64 & 5 & 2 & 7 & 5.69 & .124 & .990 & .980 \\
\hline 23_2A & 44 & 3 & 4 & 7 & 5.84 & .121 & .805 & .649 \\
\hline 23_2B & 52 & 3 & 4 & 7 & 5.94 & .115 & .826 & .683 \\
\hline 23_3\&4 & 57 & 4 & 3 & 7 & 6.02 & .124 & .935 & .875 \\
\hline 24_1B & 64 & 5 & 2 & 7 & 5.72 & .119 & .951 & .904 \\
\hline 24_2A & 44 & 3 & 4 & 7 & 5.80 & .124 & .823 & .678 \\
\hline 24_2B & 52 & 3 & 4 & 7 & 5.87 & .129 & .929 & .864 \\
\hline 24_3\&4 & 57 & 3 & 4 & 7 & 6.05 & .124 & .934 & .872 \\
\hline
\end{tabular}



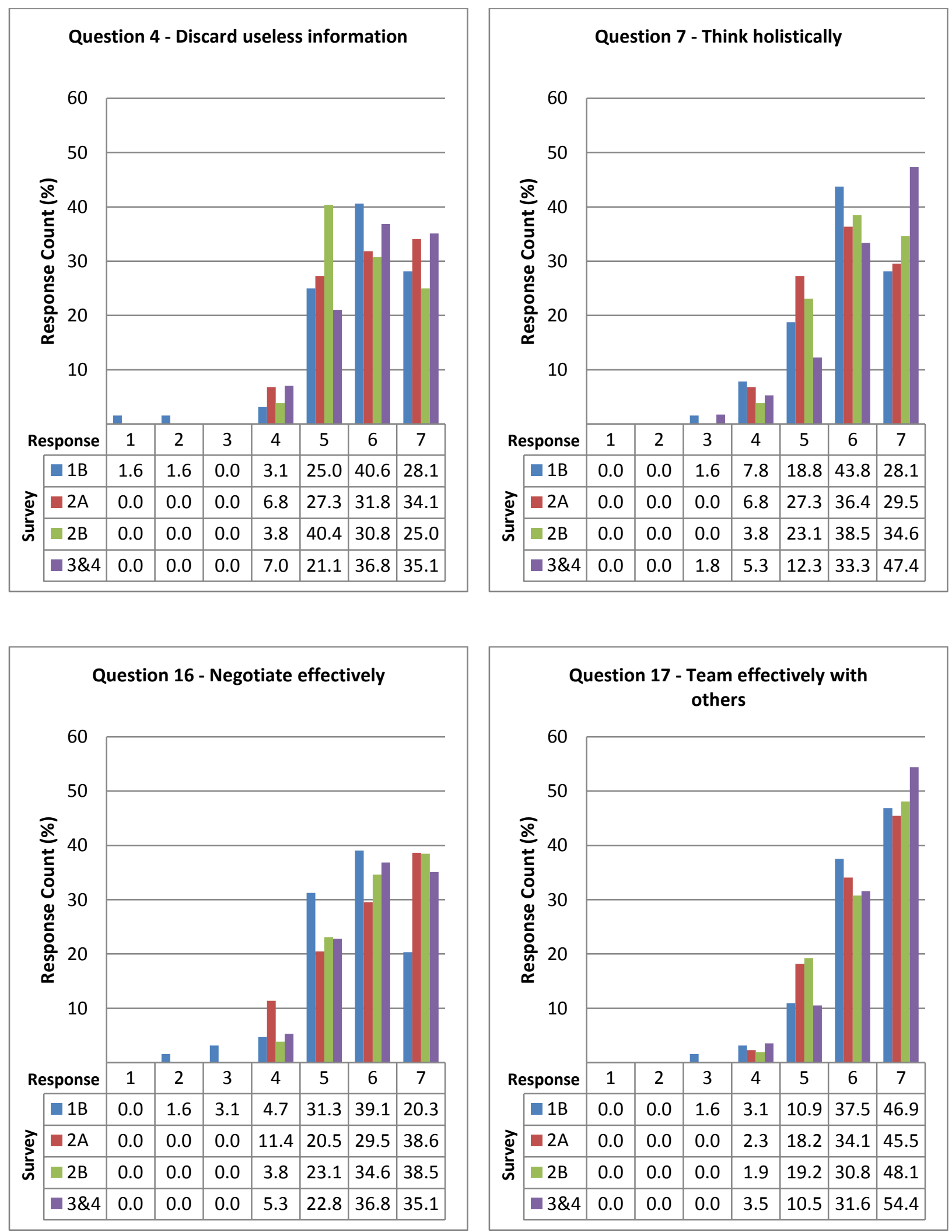

Figure 5 - Histograms of Response Count (\%) across Surveys - Questions 4, 7, 16 and 17 

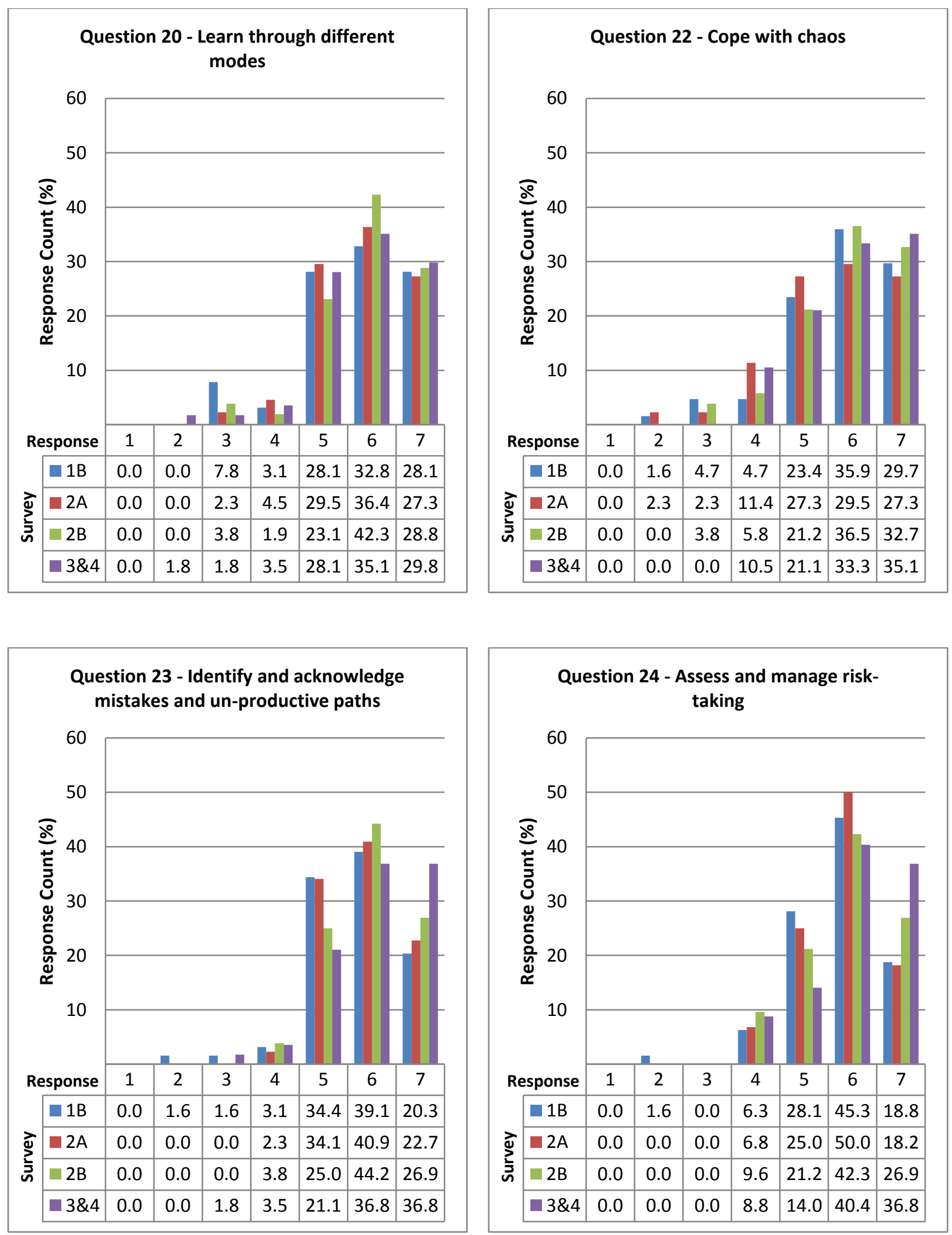

Figure 6 - Histograms of Response Count (\%) across Surveys - Questions 20, 22, 23 and 24 
Having presented the responses to each question, the final view of the data given is of some student responses. Shown in Figures 7, 8, 9, and 10 are the responses of some sample students selected at random from the set of students completing all surveys. Based on their final grade for the course, an "A", "B", "C" and an "F" student's responses are given.

The perceptions of competence appear to correlate reasonably with the grade achieved, at least for the sample students shown. Comparatively, those achieving high grades can be seen to be claiming higher levels of competence. It is also evident that the students generally and independent of grade have identified increased levels of perceived competence as they transition through the course. There are a few exceptions where it is hypothesized that students have corrected over estimates of competence based on their own reflections and perhaps the formative feedback provided during the course.

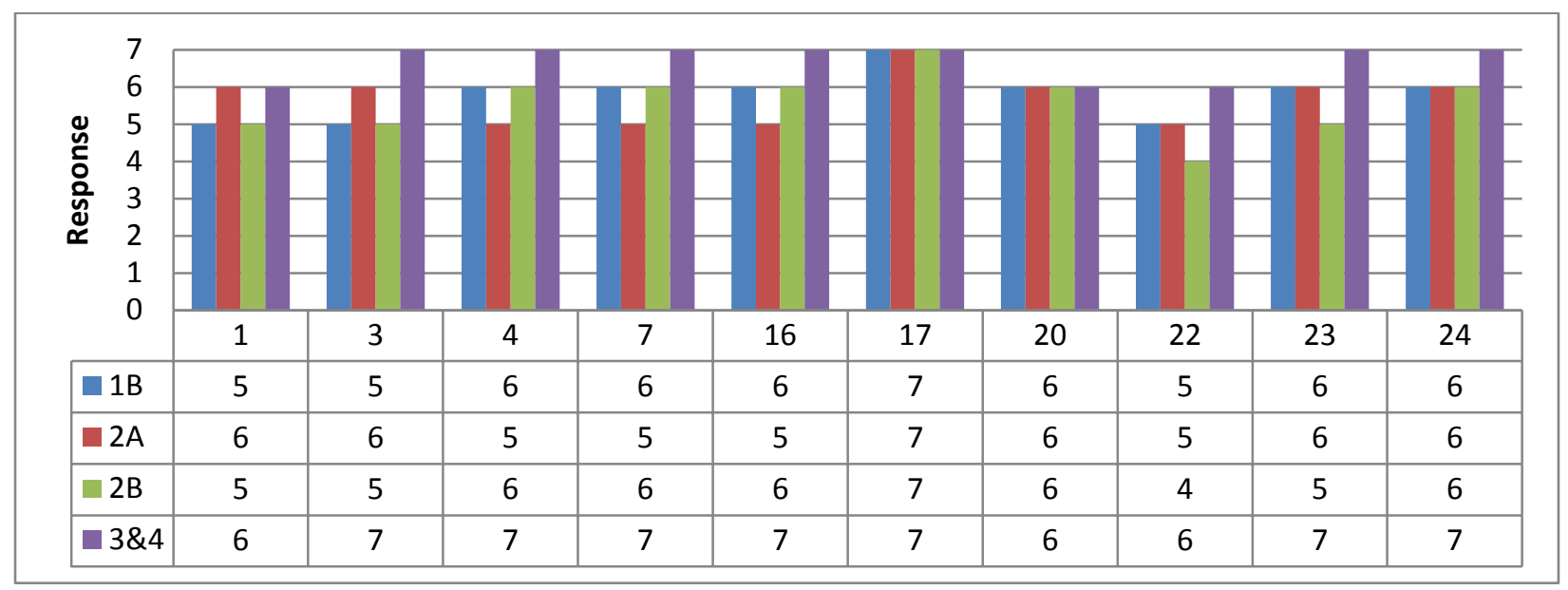

Figure 7 - Histograms of Response by an "A" Student

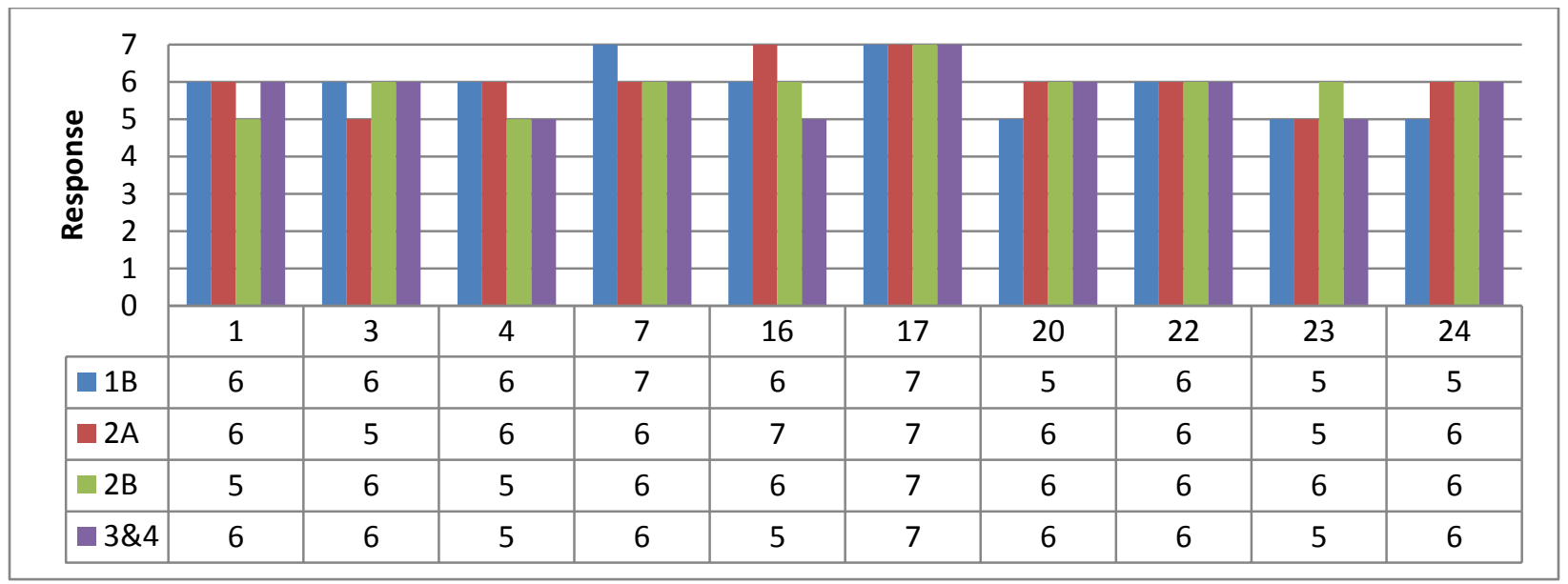

Figure 8 - Histograms of Response a "B" Student 


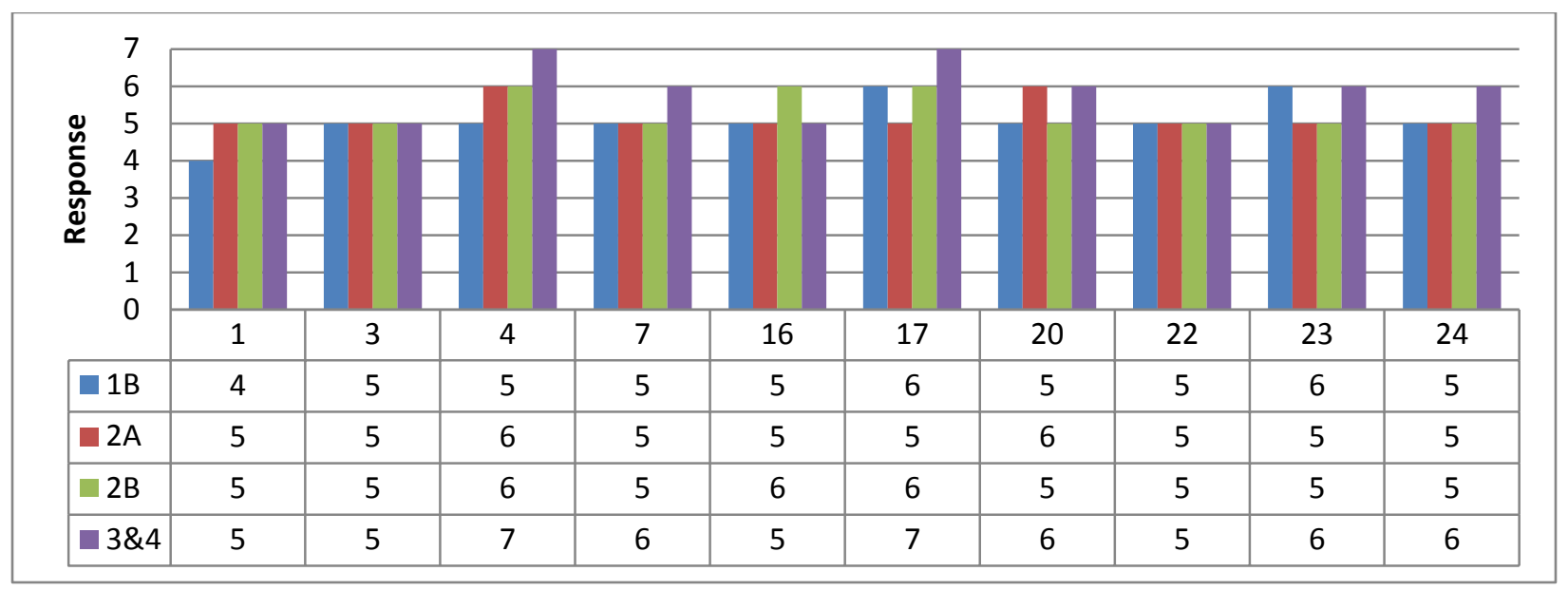

Figure 9 - Histograms of Response by a "C" Student

\begin{tabular}{|c|c|c|c|c|c|c|c|c|c|c|}
\hline \multirow{6}{*}{ 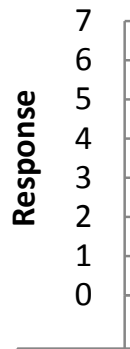 } & & & & & & & & & & \\
\hline & & & & & & & & & & \\
\hline & & & & & & & & & & \\
\hline & & & & & & & & & & \\
\hline & & & & & & & & & & \\
\hline & 1 & 3 & 4 & 7 & 16 & 17 & 20 & 22 & 23 & 24 \\
\hline $1 \mathrm{~B}$ & 4 & 4 & 5 & 5 & 4 & 4 & 5 & 4 & 5 & 5 \\
\hline$-2 \mathrm{~A}$ & 4 & 5 & 5 & 5 & 6 & 5 & 6 & 5 & 5 & 4 \\
\hline $2 \mathrm{~B}$ & 5 & 5 & 5 & 5 & 5 & 5 & 6 & 5 & 5 & 5 \\
\hline $3 \& 4$ & 5 & 6 & 5 & 5 & 6 & 5 & 6 & 4 & 5 & 5 \\
\hline
\end{tabular}

Figure 10 - Histograms of Response by an "F" Student

\section{Conclusions and Future Work}

The results presented represent the initial findings of a work in progress aimed at documenting student perceptions of their developing competencies. This activity ties to some parallel work examining student motivation and performance. Our answers to the fundamental questions are as follows.

\section{How do students perceive their competence while executing a design project?}

A portion of the collected data has been summarized and discussed but the strong result is that students have emphatically shown they have perceived increases in their competency level during the conduct of the subject course. Observations from students' perception s of competencies indicate that the design project and course did influence the students' views on competencies, irrespective of grades obtained for the course. We believe that a learning environment that allows students to work on ill-structured problems, using a prescriptive design process has the necessary elements to support productive growth of technical and general 
competencies. This is not just a pleasing result validating the academics involved but it is an exciting result that deserves further investigation. The hypothesis was that students would recognize their competencies developing through team-based and self-learning activities. The desire to understand students' awareness of their own learning and development is foundational / fundamental. Students' self-reported competency data fluctuated and adjusted as the semester progressed, suggesting this indicates that student perceptions are a reasonable indicator to gauge development of competencies.

\section{How does the perception of a set of competencies develop in design courses?}

Tracking the perceived level of competencies of students in AME 4163, we believe that development of competencies, even in one course, goes through several phases:

i. Initial Estimation: During this phase students make an initial estimate of their level of competencies. We believe that this estimate is usually based on performance from previous courses.

ii. Calibration: During the second phase students readjust their level of competencies. We believe that this is because the students encounter different hurdles when performing tasks related to different competencies, which usually results in a considerable reduction in their self-perception.

iii. Recovery: During the third phase, students are more aware of their level of competencies and start to recover their perception of competency levels. The recovery is due to further development of competencies through additional tasks related to development of specific competencies. The recovery process continues as students perform activities to develop the same/similar competencies and is often preceded by re-estimation and recalibration.

In engineering curriculum and courses multiple opportunities need to be provided for students to go through these phases multiple times. The phases being spoken about are most evident in the dips in the curves shown in Figure 3(a). It is noticeable that the dips do not all occur at the same time. They are also represented in the histograms for the individual students (Figures 6, 7, 8 and 9) where the responses from one survey to the next are not monotonic. We believe this indicates that the process of development of competencies in students is dependent on individual characteristics. Also noticeable is that senior engineering students, in most instances, perceive themselves as moderate to highly competent. The ill structured problem and design course provides an environment to adjust and develop their competencies further.

Opportunities for further work include mining the data already collected for additional results, particularly through correlation with assessment and demonstration of true competence. A lot more can be gleaned from all the questions asked but that goes beyond the scope of this conference paper. Repeating the study with the following cohort of students and students from other campuses to further validate and confirm findings would also be a natural extension to the work. Finally, making use of the students' learning essays as a source of further qualitative data, providing insight into their perceptions presents another analytical opportunity.

To conclude, a student's summary statement at the end of the class is provided. He wrote "upon review of the competencies that I wanted to develop in this class and based on the lessons learned, I believe I have developed my competencies. (As examples) I developed (my) creativity in pursuit of a solution through the use of function structures and morphological charts. I 
developed (my) analytical skills using a variety of tools. In addition to learning the design process steps, I now have experience in the process and have developed (my) insights to apply in the future."

\section{Acknowledgements}

The participation of the students in this study by completing the surveys is acknowledged and they are thanked for their commitment to assisting the conduct of this research in this way.

We thank The University of NSW, Australia, for the support of Warren Smith's sabbatical with the Systems Realization Laboratory at OU, during which time the authors had the opportunity of working together and completing this work.

Farrokh Mistree gratefully acknowledges the support he receives as the LA Comp Chair.

This material is based in part upon work supported by the National Science Foundation under Grant Numbers DUE- 1141238. Any opinions, findings, and conclusions or recommendations expressed in this material are those of the author(s) and do not necessarily reflect the views of the National Science Foundation.

\section{References}

1. $\quad$ Lamancusa, J.S., Jorgensen, J.E., and Zayas-Castro, J.L., The learning factory-A new approach to integrating design and manufacturing into the engineering curriculum. Journal of Engineering Education, 1997. 86(2): p. 103-112.

2. $\quad$ Lamancusa, J.S., Jorgensen, J.E., Zayas-Castro, J.L., and De Ramirez, L.M. The Learning FactoryIntegrating Design, Manufacturing and Business Realities into Engineering Curricula-a Sixth Year Report Card. in International Conference on Engineering Education. 2001. Oslo, Norway.

3. Shah, J., Sadowsky, J., Macia, N., Woodfill, M., and Wilson, A. The virtual corporation: simulating real World collaborative design in a university setting. in Design Theory and Methodology Conference. 1995. Boston, MA: ASME.

4. Simpson, T., Medeiros, D., Joshi, S., Wysk, R., and Lehtihe, A. IME, Inc. - A New Course for Integrating Design, Manufacturing, and Production into the Engineering Curriculum. in American Society for Engineering Education Annual Conference \& Exposition. 2001. Albuquerque, NM: ASEE.

5. Bright, A., Teaching and learning in the engineering clinic program at Harvey Mudd College. Journal of Engineering Education, 1994. 83(1): p. 113-116.

6. Back, W.E. and Sanders, S.R., Industry expectations for engineering graduates. Engineering, Construction and Architectural Management, 1998. 5(2): p. 137-143.

7. Magin, D. and Kanapathipillai, S., Engineering students' understanding of the role of experimentation. European journal of engineering education, 2000. 25(4): p. 351-358.

8. Endsley, M.R., Expertise and situation awareness, in The Cambridge handbook of expertise and expert performance, K.A. Ericsson, N. Charness, P.J. Feltovich, and R.R. Hoffman, Editors. 2006, Cambridge University Press: New York. p. 633-652. 
9. Roberts, T.G., A Philosophical Examination of Experiential Learning Theory for Agricultural Educators. Journal of Agricultural Education, 2006. 47(1): p. 17-29.

10. Dym, C.L., Agogino, A.M., Eris, O., Frey, D.D., and Leifer, L.J., Engineering Design Thinking, Teaching and Learning. Journal of Engineering Education, 2005. 94(1): p. 103-119.

11. Bradford School of Technical Management, Managerial Skills and Expertise Used by Samples of Engineers in Britain, Australia, Western Canada, Japan, the Netherlands and Norway. 1984: University of Bradford: Bradford, UK.

12. Evers, F.T., Rush, J.C., and Berdrow, I., The Bases of Competence: Skills for Lifetime Learning and Employability. Jossey-Bass Higher and Adult Education Series. 2005, Guelph, Ontario: Jossey-Bass Publishers.

13. McLaughlin, M., Employability Skills Profile: What Are Employers Looking For? 1992: Ottawa, ON, Conference Board of Canada.

14. Sparkes, J.J., Quality in Engineering Education. International Journal of Continuing Engineering Education and Life-Long Learning, 1990. 1(1): p. 18-32.

15. Engineering Accreditation Commission, Criteria for accrediting engineering programs. ABET Inc., USA, 2007.

16. Feltovich, P.J., Prietula, M.J., and Ericsson, K.A., Studies of Expertise from Psychological Perspectives, in The Cambridge handbook of expertise and expert performance, K.A. Ericsson, N. Charness, P.J. Feltovich, and R.R. Hoffman, Editors. 2006, Cambridge Press: New York, NY. p. 41-67.

17. Armarego, J. and Roy, G.G., Curriculum assessment for professional accreditation: A modelling framework. Australasian Journal of Engineering Education, 2013. 19(1): p. 1-11.

18. Woollacott, L.C., Validating the CDIO syllabus for engineering education using the taxonomy of engineering competencies. European Journal of Engineering Education, 2009. 34(6): p. 545-559.

19. Chubin, D.E., May, G.S., and Babco, E.L., Diversifying the engineering workforce. Journal of Engineering Education, 2005. 94(1): p. 73-86.

20. Felder, R.M., Sheppard, S.D., and Smith, K.A., A new journal for a field in transition. Journal of Engineering Education, 2005. 94(1): p. 7-12.

21. Mistree, F., Ifenthaler, D., and Siddique, Z. Empowering Engineering Students to Learn How To Learn: A Competency-based Approach. in ASEE Annual Conference and Exposition. 2013. Altanta, GA: American Society for Engineering Education.

22. Dai, D.Y. and Sternberg, R.J., Motivation, emotion, and cognition: Integrative perspectives on intellectual functioning and development. 2004, Mahwah, NJ: Lawrence Erlbaum.

23. Ericsson, K.A., The Influence of Experience and Deliberate Practice on the Development of Superior Expert Performance, in The Cambridge handbook of expertise and expert performance, K.A. Ericsson, N. Charness, P.J. Feltovich, and R.R. Hoffman, Editors. 2006, Cambridge University Press: New York. p. 685-706.

24. Bandura, A., Self-efficacy: The exercise of control. 1997: W.H. Feeman and Company.

25. Ryan, R.M. and Deci, E.L., Intrinsic and extrinsic motivations: Classic definitions and new directions. Contemporary educational psychology, 2000. 25(1): p. 54-67.

26. Zimmerman, B.J., Development and adaptation of expertise: the role of self-regulatory processes and beliefs, in The Cambridge handbook of expertise and expert performance, K.A. Ericsson, N. Charness, P.J. Feltovich, and R.R. Hoffman, Editors. 2006, Cambridge University Press: New York. p. 705-722.

27. Allan, M. and Chisholm, C.U., Achieving engineering competencies in the global information society through the integration of on-campus and workplace environments. Industry and Higher Education, 2008. 22(3): p. 145-152.

28. Earnest, J. and Hills, S. ABET engineering technology criteria and competency based engineering education. in ASEE/IEEE Frontiers in Education, 2005. FIE'05. Proceedings 35th Annual Conference. 2005. Indianapolis, IN: IEEE.

29. Male, S.A., Bush, M.B., and Chapman, E.S., An Australian study of generic competencies required by engineers. European Journal of Engineering Education, 2011. 36(2): p. 151-163. 
30. Radcliffe, D.F., Innovation as a meta attribute for graduate engineers. International Journal of Engineering Education, 2005. 21(2): p. 194-199.

31. Wulf, W.A. and Fisher, G., A Makeover for Engineering Education. Issues in Science and Technology, 2002. 18(3): p. 35-39.

32. Caird, S., Problems with the identification of enterprise competencies and the implications for assessment and development. Management Learning, 1992. 23(1): p. 6-17.

33. Hamel, G. and Prahalad, C., The Core Competence of the Corporation. Harvard Business Review, 1990. 3 : p. 75-91.

34. Bloom, B., Taxonomy of Educational Objectives, Handbook I: The Cognitive Domain. New York: David McKay Co Inc. 1956.

35. Pohl, M., Learning to Think Thinking to Learn: Models and Strategies to Develop a Classroom Culture of Thinking. 2000, Cheltenham, Vic: Hawker Brownlow Education.

36. Hawthorne, B., Sha, Z., Panchal, J.H., and Mistree, F. Developing competencies for the 21 st century engineer. in ASME 2012 International Design Engineering Technical Conferences and Computers and Information in Engineering Conference. 2012. Chicago, IL: American Society of Mechanical Engineers.

37. Siddique, Z., Panchal, J., Schaefer, D., Haroon, S., Allen, J.K., and Mistree, F. Competencies for innovating in the 21st century. in ASME 2012 International Design Engineering Technical Conferences and Computers and Information in Engineering Conference. 2012. Chicago, IL: American Society of Mechanical Engineers.

38. Bonwell, C.C. and Eison, J.A., Active Learning: Creating Excitement in the Classroom, ASHE-ERIC Higher Education Report Number 1. 1999, Washington, DC.: The George Washington University, School of Education and Human Development.

39. Davis, C. and E., W., Teaching Materials using Case Studies. 2005, Liverpool, UK: UK center for Materials Education, University of Liverpool.

40. White, H.B., Dan tries Problem-Based Learning: A case study, To Improve the Academy. Higher Education, 1996. 15: p. 75-91.

41. Bransford, J., Brown, A., and Cocking, R., How people learn: Mind, brain, experience, and school. Washington, DC: National Research Council, 1999. 